\title{
Cystoscopic suture removal by Holmium-YAG laser after Burch procedure
}

\author{
Burch kolposuspensiyonu sonrası mesane içi sütürün Holmium-YAG lazer ile çıkanlması
}

\author{
Emre Kazım Karaşahin ${ }^{1}$, Sertaç Esin ${ }^{1}$, İbrahim Alanbay ${ }^{1}$, Mutlu Cihangir Ercan ${ }^{1}$, Erol Mutlu', İskender Başer1, SSeref Basal ${ }^{2}$ \\ 'Department of Obstetrics and Gynecology, Gulhane Military Medical Faculty, Ankara, Turkey \\ 2Department of Urology, Gulhane Military Medical Faculty, Ankara, Turkey
}

\section{Abstract}

Burch colposuspension remains one of the successful operations performed for stress incontinence. Accidental suturing of the bladder wall during the procedure or subsequent erosion may lead to lower urinary tract symptoms. Diagnosis and management of these sutures indicate precise evaluation for which a 70 degree cystoscope is used. In selected cases, Holmium-YAG laser may enable us to manage longstanding, encrustated neglected sutures. Here we would like to report successful removal of intravesical sutures using the Holmium-YAG laser. (J Turkish-German Gynecol Assoc 2011; 12: 56-8)

Key words: Burch colposuspension, stress incontinence, cystoscopy, Holmium-YAG laser

Received: 10 April, 2010

Accepted: 10 June, 2010
Özet

Burch kolposüspansiyonu stres inkontinans tedavisinde kullanılan en başarılı tedavilerden biri olmaya devam etmektedir. İşlem esnasında sütürün yanlışlıkla mesane duvarından geçmesi yada daha sonra gelişen erozyon nedeniyle sütürün mesane içinde kalması alt üriner sistem semptomlarına yol açmaktadır. Bu sütürlerin belirlenmesi ve ortadan kaldırılmasında ayrıntılı inceleme ve bunun için daha çok 70 derecelik sistoskopun kullanılması gerekmektedir. Seçilmiş vakalarda, uzun süre içeride kalmış ve katılaşmış sütürün çıkarılmasında Holmium-YAG lazer özellikle yardımcı olabilir. Bu vakada, intravesikal sütürlerin Holmium-YAG lazer ile başarılı şekilde çıkarılması anlatılmaktadır. (J Turkish-German Gynecol Assoc 2011; 12: 56-8)

Anahtar kelimeler: Burch kolposüspansiyonu, stres inkontinans, sistoskopi, Holmium-YAG lazer

Geliş Tarihi: 10 Nisan 2010

Kabul Tarihi: 10 Haziran 2010

\section{Introduction}

Burch colposuspension is a widely employed surgical treatment for genuine stress incontinence. The paraurethral vaginal wall is attached to Cooper's (Iliopectineal) ligament by polypropylene sutures to correct deficient urethral closure. Inadvertent suturing of the bladder wall during the procedure or subsequent erosion may lead to a foreign body reaction, resulting in new or worsening of preexisting symptoms (1). The localization of the sutures is usually at the dome of the bladder which complicates the diagnosis and management. The Holmium-YAG laser is a solid-state pulsed laser frequently used for benign prostatic hyperplasia and urolithiasis (2). Here we would like to report endoscopic excision of intravesical propylene suture using Holmium-YAG laser.

\section{Case}

A 42-year-old woman presented to our hospital's urology department with chronic pelvic pain and recurrent urinary tract infection. She was evaluated, urinanalysis was normal and then an office cystoscopy with a rigid 30 degrees cystoscope was performed, which was reported as normal. Thereafter, the patient was referred for consultation with our department.
She was a G2P2 patient and her medical history was unremarkable except for a Burch Colposuspension operation she had undergone 2 years previously in a district hospital due to stress incontinence. The operation record was not available and according to the patient's statements, 1 day after the operation, she underwent a cystoscopy which was reported verbally as "normal". Her stress incontinence disappeared but soon after, frequency, urgency, dyspareunia, pelvic pain and recurrent urinary tract infection complaints ensued. In our clinic, the vaginal examination was normal and transvaginal sonography revealed no abnormalities in the uterus and ovaries. Her urine tests were repeated and only mild hematuria was detected. Renal ultrasonography was also normal. She was reevaluated in the gynecology and urology council and the decision was to perform a repeat cystoscopy. Under general anesthesia, we performed rigid cystoscopy with a 70 degree cystoscope. In the cystoscopy, we detected polypropylene sutures at the vesical neck both on the right and left sides close to the dome of the bladder. The sutures were surrounded by edematous inflamed bladder mucosa and granulation tissue. We attempted to cut the suture using the cystoscopic scissors but this was unsuccessful due to hardening by partial encrustation. After an intraoperative urology consultation, we decided to use the Holmium-YAG laser. 
The VersaPulse® PowerSuite ${ }^{\mathrm{TM}} 100 \mathrm{~W}$ was used. The HolmiumYAG laser output was $1.2 \mathrm{~J}$ per pulse at a rate of $5 \mathrm{~Hz}$. Through the channel of the cystoscope, the Holmium-YAG laser was advanced using a $365 \mu \mathrm{m}$ tip firing fiber and intravesical portions of the polypropylene sutures were resected on both sides (Figure 1). These resected portions were removed through the cystoscope. Total operation time was 12 minutes. The postoperative course was uneventful. 3 months later, the patient was free of all her complaints but dyspareunia.

\section{Discussion}

Burch colposuspension is the most widely performed retropubic operation for stress incontinence and attempts to reestablish the anatomic position of the bladder neck by elevating the endopelvic fascia. Non-absorbable sutures have been recommended for Burch colposuspension (3). Inadvertent placing of the sutures through the bladder at the time of surgery or postoperative erosion or migration of the sutures into the bladder (4) may cause chronic inflammatory reaction in the wall of the bladder, resulting in lower urinary tract symptoms. In our case, it was not possible to ascertain the exact mechanism of suturing the bladder wall due to nonavailability of the original operative record.

Dwyer et al. (5) reported intravesical sutures in $3(0,32 \%)$ out of 925 cases who underwent open Burch colposuspension. No matter the suture is accidentally placed or later migrates into the bladder, intravesical sutures are an important complication of Burch colposuspension. Timely diagnosis of these injuries is associated with lower morbidity and costs, and we agree with Patel et al. (6) that routine use of cystoscopy at the time of colposuspension may enable clinicians to detect and repair the defect concurrently. Suture injuries to the urinary tract in urethral suspension procedures for stress incontinence usually occur at 1 and 11 o'clock. As can be seen in our case, after the Burch procedure, cystoscopic examination by a 30 degree cystoscope may be inadequate. This highlights the necessity of using a 70 degree cystoscope (6).

The Holmium-YAG laser is currently the workhorse laser in urology since it can be used for multiple soft- and hard-tissue applications, including benign prostate hyperplasia (7), laser lithotripsy (8), bladder tumors and strictures. Besides these, it may also be used for excision of intravesical foreign bodies such as tension-free vaginal tape or polypropylene suture (9). During cystoscopy, due to the localization of intravesical sutures (6), it may be difficult for the physician to reach and work in these localizations. In our case, cystoscopic scissors were unsuccessful in cutting the polypropylene suture. For these challenging cases, Holmium-YAG laser is an attractive option for cutting and removing these sutures. Holmium-YAG laser material fragmentation depends upon two mechanisms. In the first mechanism, absorbed laser energy at the focus point melts and breaks down the object. In the second, if the energy used is high, the atomic structure of the material is burst (10). The safety of the Holmium-YAG laser has been shown for prostate (7), urinary calculi (8) and intravesical foreign bodies (10). The wavelength of Holmium-YAG laser is very near the absorption peak of water, thus surrounding tissue damage is minimized provided that water is present $(8,10)$. Precise targeting is important to prevent uroepithelial injury and this is highly unlikely if the distance between the tip of the fiber and the urothelium is greater than 0, $5 \mathrm{~mm}$ (8). In addition, among other laser types, Holmium-YAG laser has the lowest tissue penetration depth (10). In conclusion, after the Burch procedure, a 70 degree cystoscopic evaluation may be helpful in order to visualize inadvertent injury to the bladder, and when intravesical sutures may not be managed by conventional cystoscopic techniques, the Holmium-YAG laser is a minimally invasive solution. Given the fact that it is easy to use and safe, the Holmium-YAG laser is an attractive option for the physician.
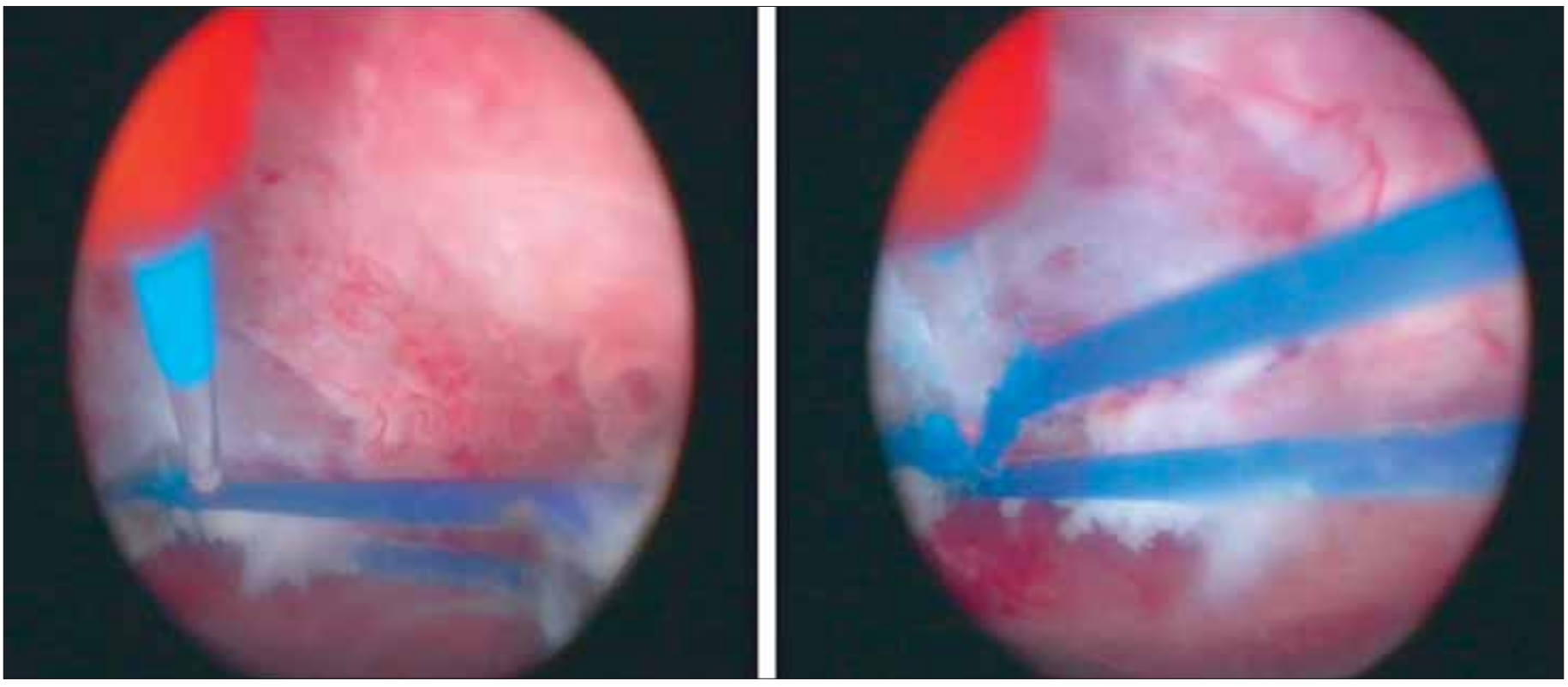

Figure 1. Resection of the polypropylene suture on the left side by Holmium-YAG laser 
Conflict of interest

None declared.

\section{References}

1. Manikandan R, Pritchard S, Brown SC. An unusual complication of Burch colposuspension. Int J Urol. 2004; 11: 669-70. [CrossRef]

2. Wollin TA, Denstedt JD. The Holmium-YAG laser in urology. J Clin Laser Med Surg 1998; 16: 13-20.

3. Stanton SL. Surgical management of urethral sphincter. Clin Obstet Gynecol 1990; 33: 352. [CrossRef]

4. Biyani CS, Upsdell SM. An unusual foreign body in the bladder 7 years after a Stamey endoscopic bladder neck suspension. Int. Urogynecol. J. Pelvic Floor Dysfunct. 1998; 9: 303-4. [CrossRef]
5. Dwyer PL, Carey MP, Rosamilia A. Suture injury to the urinary tract in urethral suspension procedures for stres incontinence. Int Urogynecol J Pelvic Floor Dysfunct 1999; 10: 15-21. [CrossRef]

6. Patel H, Bhatia N. Universal cystoscopy for timely detection of urinary tract injuries during pelvic surgery. Curr Opin Obstet Gynecol. 2009; 21: 415-8. [CrossRef]

7. Kuntz RM. Laser treatment of benign prostatic hyperplasia. World J Urol 2007; 25: 241-7. [CrossRef]

8. Pierre S, Preminger GM. Holmium-YAG laser for stone management. World J Urol 2007; 25: 235-9. [CrossRef]

9. Giri SK, Drumm J, Flood HD. Endoscopic Holmium-YAG laser excision of intravesical tension-free vaginal tape and polypropylene suture after anti-incontinence procedures. J Urol. 2005; 174: 1306-7. [CrossRef]

10. Bedke J, Kruck S, Schilling D, Matter A, Horstmann M, Sievert KD et al. Laser fragmentation of foreign bodies in the urinary tract: an in vitro study and clinical application. World J Urol. 2010; 28: 16.

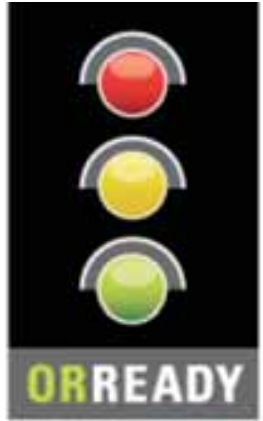

We are ORReady and support operating room safety to improve patient outcome.
ORReady is a worldwide, multi-Specialty initiative to encourage steps that are known to improve surgical outcomes and save lives.

If the suggested guidelines, which include Check Lists, Time Outs and Warm Ups are followed routinely, we estimate that Six Million patients around the world could have better outcomes.

Find out how your department and hospital can be ORReady and improve outcomes at http://www.sls.org/outcome 